\title{
Applying quality status criteria to a temperate estuary before and after the mitigation measures to reduce eutrophication symptoms
}

\author{
A.I. Lilleb $\varnothing^{\text {a,b,* }}$, H. Teixeira ${ }^{\text {a }}$, M.A. Pardal ${ }^{\text {a }}$, J.C. Marques ${ }^{\text {a }}$ \\ a IMAR - Institute of Marine Research, Department of Zoology, University of Coimbra, 3004-517 Coimbra, Portugal \\ ${ }^{\mathrm{b}}$ CESAM - Centro de Estudos do Ambiente e do Mar, University of Aveiro, 3810-193 Aveiro, Portugal
}

Received 21 June 2006; accepted 23 October 2006

Available online 4 December 2006

\begin{abstract}
The Mondego estuary is a well-described polyhaline type of transitional water located at the North Atlantic Ocean Ecoregion, where cultural eutrophication progressed over the last decades of the 20th century. Consequently, and due to huge productivity of Ulva spp. Zostera noltii meadows were severely reduced causing the whole ecosystem to become impoverished in terms of macrofaunal abundance, biomass and species richness with a concomitant lowering of secondary production. In 1998, experimental mitigation measures were implemented, via changes in hydrology to increase circulation and diversion of nutrient rich freshwater inflow, to reverse the process in the most affected area of the estuary its south arm. Thus, the system quality status was assessed before and after 1998, over a ten year period. The OSPAR comprehensive procedure, the first phase of the US-NEEA procedure and the proposed EU-WFD physicochemical status criteria were applied to the data before and after the modifications and all show that the system health has improved. Nonetheless, the annual means of the oxidised forms of nitrogen and of phosphate were not reduced. In fact, applying criteria used in classifying the nutrient levels in transitional waters and the Baltic sea trophic condition, the system has not improved. Meaning that, to look forward to a "higher" quality status, future measures should also consider longer term solutions such as improved agriculture practices in the Mondego River valley through environmental friendly technological solutions that will reduce the nutrient loads to this system.
\end{abstract}

(C) 2006 Elsevier Ltd. All rights reserved.

Keywords: eutrophication; transitional waters; quality status; estuary

\section{Introduction}

Over the last decades, many coastal and marine water bodies have experienced a high anthropogenic loading of nutrients, named as cultural eutrophication (e.g. Hauxwell and Valiela, 2004). Eutrophication can be defined as "the enrichment of water by nutrients, especially compounds of nitrogen and/or phosphorus causing an accelerate growth of algae and higher forms of plant life to produce and undesirable

\footnotetext{
* Corresponding author. CESAM - Centro de Estudos do Ambiente e do Mar, University of Aveiro, 3810-193 Aveiro, Portugal.

E-mail address: lillebo@dq.ua.pt (A.I. Lilleb $\varnothing$ ).
}

disturbance to the balance of organisms present in the water and to the quality of the water concerned" (UWWT Directive 91/271/EEC) in Crouzet et al. (1999). Nowadays, this process is a common thread that links a wide range of problems along many coastal areas worldwide (e.g. Meeuwing, 1999; Cloern, 2001; Hauxwell and Valiela, 2004). Thus several countries have been developing criteria and tools in order to evaluate the ecological status of these coastal systems so as to implement measures aiming to improve the water physicochemical and biological status.

Relevant examples are the Convention for the Protection of the Marine Environment of the North-East Atlantic (OSPAR Convention) (OSPAR Commission, 2005a), the European Union Water Framework Directive (EU-WFD) (Directive, 
2000/60/EC), the United States National Estuarine Eutrophication Assessment (US-NEEA) (Bricker et al., 1999), and the Helsinki Commission - Baltic Marine Environment Protection Commission (HELCOM) (HELCOM's website: http://www.helcom.fi). As stated in the OSPAR Commission (2005a,b), the concept of the OSPAR EcoQOs (Ecological Quality Objectives) can be linked to the activities within the European Water Framework Directive, namely the European Marine Strategy (Borja, 2005). In fact, monitoring and assessment under the WFD aims to evaluate progress made towards the objective to achieve, by 2015, "good surface water status", meaning that "both its ecological status and its chemical status are at least good", whilst the OSPAR convention monitoring and assessment aim "to achieve by the year 2010 a healthy marine environment where eutrophication does not occur'.

There are several methods that can be used to evaluate the status of systems such as the US-NEEA method in which Bricker et al., 2003 proposed an integrated methodology for Assessment of Estuarine Trophic Status (ASSETS) aiming to contribute to the EU-WFD classification system. Moreover, for transitional waters, the Ecological Quality Status (EcoQ WFD) and the Ecological Quality Objectives (EcoQOs OSPAR) are based upon the status of the physicochemical, hydromorphological and biological quality elements. Indeed, although the concepts, terminologies and tools may be still under debate (e.g. Crane, 2003; Borja et al., 2004; Borja, 2005; Borja and Heinrich, 2005; Marín-Guirao et al., 2005; OSPAR Commission, 2005b; de Jonge et al., 2006; Teixeira et al., in press), there are synergies in monitoring requirements to assess the quality status of coastal and transitional waters (Table 1).

As for many other coastal systems, the Mondego estuary (western Portugal), has shown during the last decades of the 20th century symptoms of eutrophication, such as large macroalgal blooms (mostly Ulva spp.) followed by the reduction of the seagrass meadows (Zostera noltii covered area was reduced from $150000 \mathrm{~m}^{2}$ in 1986 to $200 \mathrm{~m}^{2}$ in $1997 \mathrm{Fig}$. 1C) (Verdelhos et al., 2005). In 1998, experimental mitigation measures were implemented in order to decrease eutrophication symptoms and to gradually start ameliorating the system's health (Lillebø et al., 2005). The objective of the present study was to assess the quality status in the Mondego estuary before and after the application of the mitigation measures implemented in 1988. In the approach to develop conclusions about how the system has changed as a result of the modifications, five methods of evaluation were used including US-NEEA, OSPAR Convention, EU-WFD method of Bald et al. (2005), Baltic sea method of Wasmund et al. (2001) and EU method of Crouzet et al. (1999) (see Table 1). In contrast to the other methods in the US-NEEA procedure nutrients are not assesses on the measurements of nutrients concentrations (DIN and DIP) but as nutrients loads.

The classifications methods for quality status enumerated in Table 1 were applied, attending to the monitoring requirements available for the south arm of the Mondego estuary. The Level of expression of eutrophic conditions assessed by the US-NEEA procedure was only addressed according to the first phase, the Overall Eutrophic Condition index. As to attend to the proposed objectives, data on nutrients (DIN and DIP), salinity, temperature, oxygen, sediment organic matter content (\%LOI) and primary producers parameters (phytoplankton chlorophyll a concentrations, green macroalgal biomass and seagrass biomass) were analysed before and after 1998, over a 10-year period.

Benthic fauna is an important component of estuarine systems, by playing an essential role in biogeochemical processes (e.g. Lillebø et al., 1999), as a food source for higher trophic levels, and as bio-indicators of the ecosystem health (e.g. Borja et al., 2004; Borja, 2005; Marín-Guirao et al., 2005). Due to that, the ecological quality of the Mondego estuary was assessed by examining the response of soft-bottom benthic fauna (Salas et al., 2004; Cardoso et al., 2005; Verdelhos et al., 2005; Teixeira et al., in press).

\section{Material and methods}

\subsection{Description of the study site}

The Mondego estuary is a warm-temperate intertidal system located on the west coast of Portugal (Fig. 1). This system is relatively small (1600 ha) and receives agricultural runoff from 15000 ha of upstream cultivated land, mainly dominated by rice fields. Since the 1930s the construction of stone walls to regulate the main navigation channels and to enlarge the harbour facilities, and the construction of small water reservoirs for agriculture and aquaculture purposes have imposed a strong anthropogenic impact in to the system. Mainly modified the riverbed topography, changed the system hydrodynamics, increased water turbidity and increased concentration of growth limiting nutrients, known as cultural eutrophication.

The Mondego estuary is about $7 \mathrm{~km}$ long and is $2-3 \mathrm{~km}$ across at its widest part, and comprises a northern and southern arm, separated by the Murraceira island. The northern arm is the deeper $( \pm 10 \mathrm{~m}$ during high tide, tidal range $0.5-3.5 \mathrm{~m})$, constituting the main navigation channel and the location of the Figueira da Foz harbour. The southern arm is shallower (2-4 $\mathrm{m}$ during high tide), and is characterised by large areas of intertidal flats exposed during low tide. Until 1998, the southern arm was almost silted up in the innermost areas, and the Mondego river outflow occurred mainly via the northern arm (Fig. 1). Water circulation in the southern arm was mostly dependent on the tides and on the freshwater input from the Pranto River, a small tributary with a flow controlled by a sluice (Fig. 1), which was regulated according to the water level of rice fields in the Mondego Valley. This freshwater input represented an important source of nutrients into the southern arm. Since 1998, the Pranto river sluice aperture was effectively reduced to lower the nutrient loading in the south arm, (most of the nutrient enriched freshwater is now diverted to the northern arm by another sluice located more upstream), and to improve the hydraulic regime the upstream connection between the two arms was enlarged, allowing water to flow from the north arm at high tide conditions. Both sluice operations are controlled by a rice farmers' association 
Table 1

Synergies in monitoring requirements to assess the quality status of coastal and transitional waters

\begin{tabular}{|c|c|c|c|c|c|c|c|c|c|c|c|c|c|c|c|c|c|}
\hline & $\begin{array}{l}\text { Assessment } \\
\text { Parameters }\end{array}$ & $\begin{array}{l}\mathrm{NO}_{3}+\mathrm{NO}_{2} \\
\left(\mu \mathrm{mol} \mathrm{L}{ }^{-1}\right)\end{array}$ & $\begin{array}{l}\mathrm{PO}_{4} \\
\left(\mathrm{mmol} \mathrm{m}^{-3}\right) \\
\left(\mu \mathrm{mol} \mathrm{L}^{-1}\right)\end{array}$ & $\begin{array}{l}\text { DIN } \\
\left(\mathrm{mmol} \mathrm{m}^{-3}\right) \\
\left.(\mu \mathrm{mol} \mathrm{L})^{-1}\right)\end{array}$ & $\begin{array}{l}\text { DIP } \\
\left(\mu \mathrm{mol} \mathrm{L}^{-1}\right)\end{array}$ & $\begin{array}{l}\mathrm{N} \text { and } \\
\mathrm{P} \text { loads } \\
\text { (ton) }\end{array}$ & $\begin{array}{l}\mathrm{N} / \mathrm{P} \\
\text { ratio }\end{array}$ & $\begin{array}{l}\text { Chl } a \\
\left(\mathrm{mg} \mathrm{m}^{-3}\right) \\
\left(\mu \mathrm{g} \mathrm{L}^{-1}\right)\end{array}$ & $\begin{array}{l}\text { Phytoplancton } \\
\text { production } \\
\left(\mathrm{g} \mathrm{C} \mathrm{m}^{-2} \mathrm{yr}^{-1}\right)\end{array}$ & $\begin{array}{l}\text { Phytoplancton } \\
\text { Biomass } \\
\left(\mathrm{mg} \mathrm{m}^{-3}\right)\end{array}$ & $\begin{array}{l}\text { Phytoplancton } \\
\text { Indicator } \\
\text { species }\end{array}$ & $\begin{array}{l}\text { Macrophytes \& } \\
\text { macroalgae }\end{array}$ & $\begin{array}{l}\text { Oxygen } \\
\text { deficiency }\end{array}$ & $\begin{array}{l}\text { Zoobenthos/ } \\
\text { fish }\end{array}$ & $\begin{array}{l}\text { Organic } \\
\text { carbon/ } \\
\text { OM }\end{array}$ & $\begin{array}{l}\text { Suspend } \\
\text { solids \& } \\
\text { turbitity }\end{array}$ & Reference \\
\hline \multirow[t]{4}{*}{$\begin{array}{l}\text { Quality } \\
\text { status }\end{array}$} & $\begin{array}{l}\text { Good } \\
\text { Fair } \\
\text { Poor } \\
\text { Bad }\end{array}$ & $\begin{array}{l}\bullet \\
\bullet \\
\bullet\end{array}$ & $\begin{array}{l}\bullet \\
\bullet \\
\bullet\end{array}$ & & & & & & & & & & & & & & $\begin{array}{l}\text { Crouzet } \\
\text { et al., 1999 } \\
\text { (Table 7.1) }\end{array}$ \\
\hline & $\begin{array}{l}\text { Oligotrophic } \\
\text { Mesotrophic } \\
\text { Eutrophic } \\
\text { Polytrophyc } \\
\text { Oligotrophic }\end{array}$ & & $\begin{array}{l}\bullet \\
\bullet \\
\bullet \\
\bullet\end{array}$ & $\begin{array}{l}\bullet \\
\bullet \\
\bullet\end{array}$ & & & & $\begin{array}{l}\bullet \\
\bullet \\
\bullet \\
\bullet\end{array}$ & $\begin{array}{l}\bullet \\
\bullet \\
\bullet \\
\bullet\end{array}$ & $\begin{array}{l}\bullet \\
\bullet \\
\bullet \\
\bullet\end{array}$ & & & & & & & $\begin{array}{l}\text { Wasmund } \\
\text { et al., 2001 } \\
\text { (Table 6) }\end{array}$ \\
\hline & $\begin{array}{l}\text { High } \\
\text { Good } \\
\text { Moderate } \\
\text { Poor } \\
\text { Bad }\end{array}$ & & & $\begin{array}{l}\bullet \\
\bullet \\
\bullet \\
\bullet\end{array}$ & $\begin{array}{l}\bullet \\
\bullet \\
\bullet \\
\bullet\end{array}$ & & $\begin{array}{l}\bullet \\
\bullet \\
\bullet \\
\bullet\end{array}$ & $\begin{array}{l}\bullet \\
\bullet \\
\bullet\end{array}$ & & $\begin{array}{l}\bullet \\
\bullet \\
\bullet \\
\bullet\end{array}$ & $\begin{array}{l}\bullet \\
\bullet \\
\bullet\end{array}$ & $\begin{array}{l}\bullet \\
\bullet \\
\bullet \\
\bullet\end{array}$ & $\begin{array}{l}\bullet \\
\bullet \\
\bullet\end{array}$ & $\begin{array}{l}\bullet \\
\bullet \\
\bullet \\
\bullet\end{array}$ & $\begin{array}{l}\bullet \\
\bullet \\
\bullet \\
\bullet\end{array}$ & & $\begin{array}{l}\text { EU-WFD } \\
\text { (Directive, } \\
\text { 2000/60/EC) }\end{array}$ \\
\hline & $\begin{array}{l}\text { Background } \\
\text { Potential PA } \\
\text { Problem Area }\end{array}$ & & & $\bullet$ & $\begin{array}{l}\bullet \\
\bullet\end{array}$ & • & : & • & & & 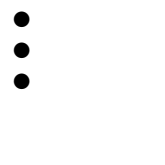 & : & • & $\ddot{\bullet}$ & : & & $\begin{array}{l}\text { OSPAR } \\
\text { Convention } \\
\text { (OSPAR } \\
\text { Commission, } \\
\text { 2005a,b) }\end{array}$ \\
\hline $\begin{array}{l}\text { Level of } \\
\text { expression } \\
\text { of eutrophic } \\
\text { conditions }\end{array}$ & $\begin{array}{l}\text { High } \\
\text { Moderate high } \\
\text { Moderate } \\
\text { Moderate Low } \\
\text { Low }\end{array}$ & & & & & $\begin{array}{l}\bullet \\
\bullet \\
\bullet \\
\bullet\end{array}$ & & $\begin{array}{l}\bullet \\
\bullet \\
\bullet\end{array}$ & & & $\begin{array}{l}\bullet \\
\bullet \\
\bullet \\
\bullet\end{array}$ & $\begin{array}{l}\bullet \\
\bullet \\
\bullet \\
\bullet\end{array}$ & $\begin{array}{l}\bullet \\
\bullet \\
\bullet\end{array}$ & $\begin{array}{l}\bullet \\
\bullet \\
\bullet \\
\bullet\end{array}$ & & $\begin{array}{l}\bullet \\
\bullet \\
\bullet \\
\bullet\end{array}$ & $\begin{array}{l}\text { Bricker } \\
\text { et al., 1999 } \\
\text { (US-NEEA) }\end{array}$ \\
\hline
\end{tabular}


A

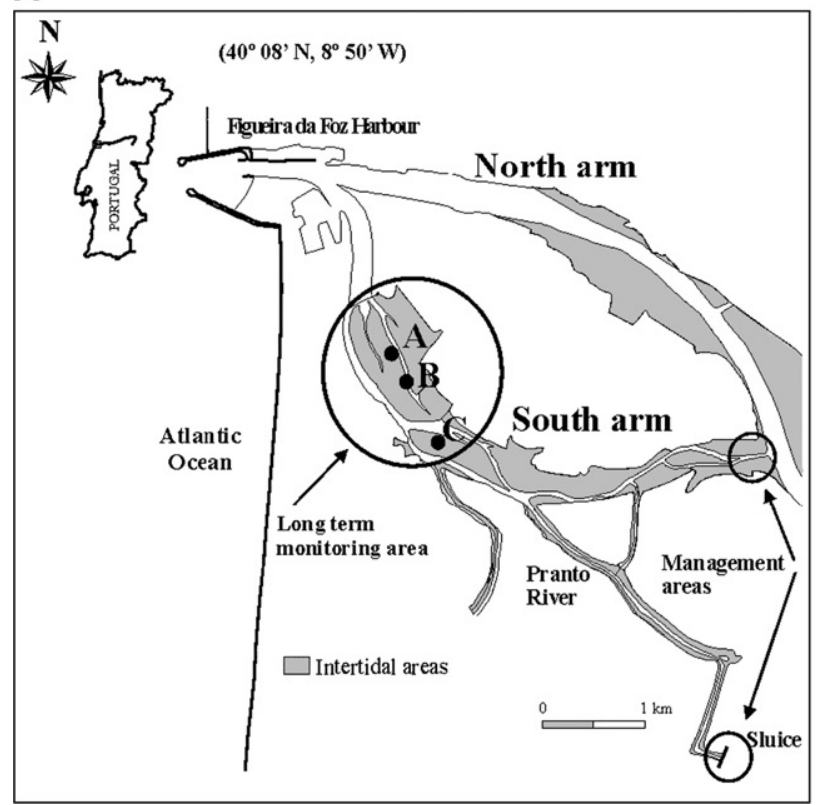

B

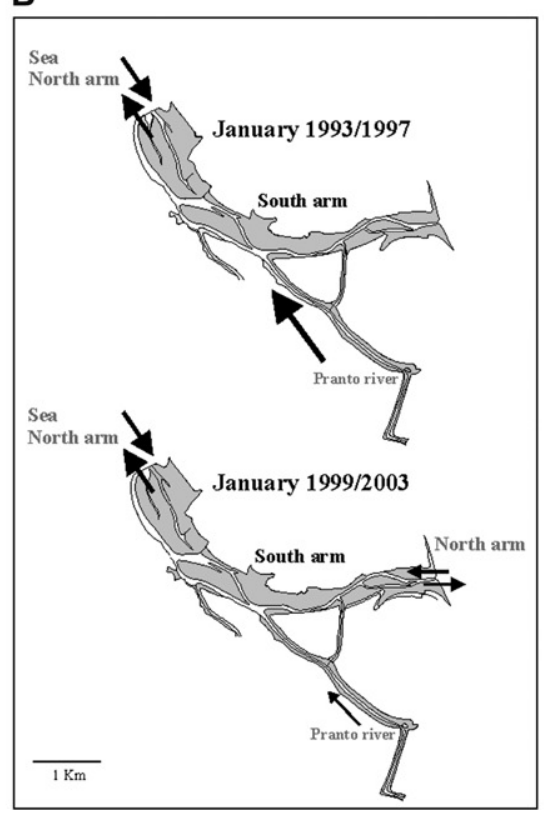

C

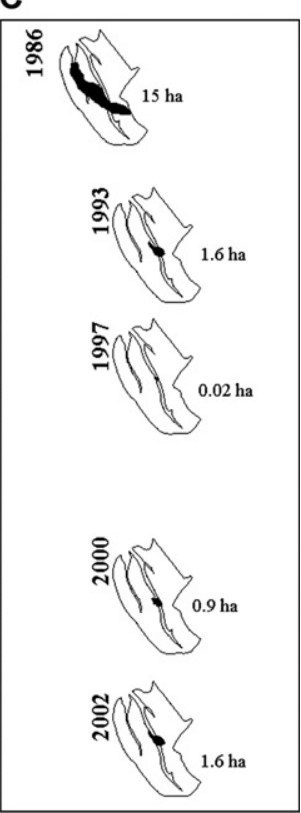

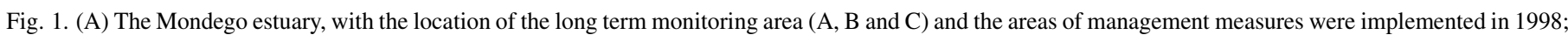

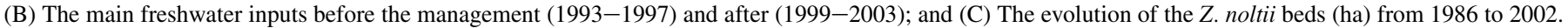

and the experimental mitigation phase in 1998 was very informal and carried out locally.

The summary of the main characteristics of the south arm of the estuary are presented in Table 2.

\subsection{Sampling procedure and analysis}

The long-term monitoring program in the Mondego estuary has been carried out since the early 1990s by an IMAR-Institute of Marine Research team, within the scope of European and national projects. In order to assess the water quality in the south arm of the estuary, three distinct areas were monitored (A, B and C in Fig. 1A). Between January 1993 and January 2003 (except in 1997/98), water temperature and salinity were measured monthly at each sampling site, during the day period just after ebbing, and water samples (approximately $250 \mathrm{ml}$ ) were collected for analysis of dissolved inorganic nitrogen and phosphorus. Samples were immediately filtered (Whatman

Table 2

Summary characterization of the south arm of the Mondego estuary, a polyhaline type (mean salinity 22) of transitional water located at the North Atlantic Ocean Ecorigion

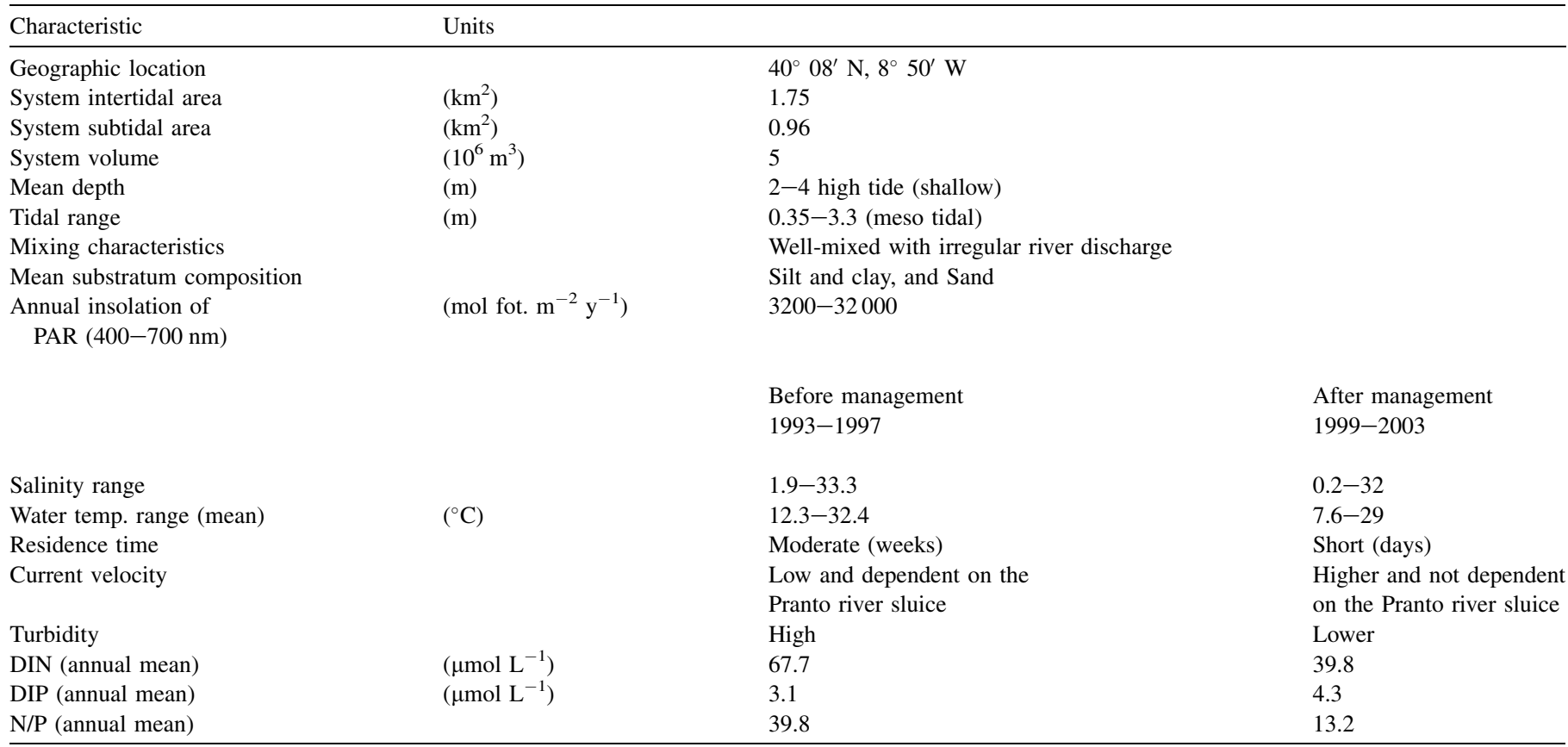


$\mathrm{GF} / \mathrm{F}$ glass-fibre filter) and stored frozen at $-18{ }^{\circ} \mathrm{C}$ until analysis following standard methods described in Limnologisk Metodik (1992) for ammonium $\left(\mathrm{NH}_{4}\right)$ and phosphate $\left(\mathrm{PO}_{4}\right)$ and in Strickland and Parsons (1972) for nitrate $\left(\mathrm{NO}_{3}\right)$, and nitrite $\left(\mathrm{NO}_{2}\right)$. In 1993, 1994, 2000 and 2001 oxygen concentrations were measure hourly through $12 \mathrm{~h}$ cycles (from 9a.m. to 9p.m.) in the main channel and for several months. The phytoplankton chlorophyll $a(\mathrm{Chl} a)$ determinations were performed by filtering $0.5-1.0 \mathrm{~L}$ of water through Whatman GF/C glass-fibre filters followed by extraction according to Parsons et al. (1985). In the field and during transportation to the lab, samples were stored on ice and light protected. Samples from the three monitoring areas (A, B and C) were collected and analysed separately. Due to the small distance between the sites, data were put together and presented/related as mean values $( \pm \mathrm{SE})$ for the south arm of the estuary.

The choice of these areas was dictated by observations of a macroalgal coverage gradient in the south arm, increasing from downstream to upstream. Originally, in the early 1980s, the three areas were covered by rooted macrophytes; however, as the eutrophication increased, together with human disturbance caused by an intensive baitdigging, Zostera noltii declined progressively. Currently, the seagrass bed is restricted to the marine end of the estuary, having been replaced elsewhere by green macroalgae. At each sampling site, primary producers and associated macrofauna were sampled monthly (minimum 6 cores, with $141 \mathrm{~cm}^{2}$ section) between January 1993 and January 2003. Green macroalgae (mostly Ulva intestinalis and Ulva compressa, according to the recent revision of Hayden et al., 2003) and the seagrass Z. noltii, were dried (for $48 \mathrm{~h}$ at $60^{\circ} \mathrm{C}$ ) and ash free dry weight (AFDW) was assessed after combustion of samples for $3 \mathrm{~h}$ at $450{ }^{\circ} \mathrm{C}$. Simultaneously, sediment samples were collected for organic matter content determination as percentage of loss on ignition (\%LOI) (Dwt-AFDW, $550{ }^{\circ} \mathrm{C}$ for $6 \mathrm{~h}$ ).

\section{Results}

\subsection{OSPAR comprehensive procedure}

For the specific ECoQOs related to eutrophication within the OSPAR Convention, the assessment parameters and the assessment levels established are referred to as area-specific "assessment level" which has been set in relation to area-specific reference or background levels, (e.g. set in relation to areaspecific and/or salinity-related background concentrations, in which the "assessment level" should not exceed 50\% of the background level), (OSPAR Commission, 2005a,b).

To apply the OSPAR Comprehensive Procedure, for the identification of the eutrophication status of the south arm of the Mondego estuary, before and after 1998, the background concentration was assumed as the oldest register, corresponding to the year of 1993 (winter mean for nutrients and annual mean for chlorophyll $a$ ), while elevated values correspond to $50 \%$ above the background concentration.

Results show that during the 1993-1997 period the winter mean DIN concentrations were above the "Elevated values" $\left(27 \mu \mathrm{mol} \mathrm{N} \mathrm{L}^{-1}\right)$ while after 1998 , between 1999 and 2002, they were mostly around the "Background concentration" $\left(18 \mu \mathrm{mol} \mathrm{N} \mathrm{L}{ }^{-1}\right)$. The annual mean chlorophyll $a$ concentrations were mostly between the "Background concentration" (5.0 $\left.\mu \mathrm{g} \mathrm{L}^{-1}\right)$ and "Elevated values" $\left(7.5 \mu \mathrm{g} \mathrm{L}^{-1}\right)$ interval, although in 1994 the mean summer concentration was above the "Elevated value" $\left(14.9 \pm 3.5 \mu \mathrm{g} \mathrm{L}^{-1}, \mathrm{SE}\right)$.

The riverine loading of $\mathrm{N}$ into the system south arm decreased from 134 tons in 1993 to 44.8 tons in 2000, whilst for the same years the $\mathrm{P}$ loading increased from 1 ton of $\mathrm{P}$ to 1.7 tons of $\mathrm{P}$ (Table 3 ).

This assessment includes four categories: I - Degree of nutrient enrichment; II - Direct effect of nutrient enrichment; III Indirect effect of nutrient enrichment; IV - Other possible effects of nutrient enrichment (Table 3). Results show that the eutrophication status of the south arm of the Mondego estuary can be classified as a "Problem Area" before 1998 and as a "Potential Problem Area" after the implemented mitigation measures (Table 3 ).

\subsection{National Estuarine Eutrophication/Assessment of Estuarine Trophic Status (US-NEEA/ASSETS)}

In the first phase of the US-NEEA procedure primary symptoms represent the first possible stage of water quality degradation associated with eutrophication (Bricker et al., 1999). These symptoms are characterized by decreased light availability, algal dominance changes and increased organic matter decomposition. The primary symptoms may lead to secondary symptoms, such as loss of submerged aquatic vegetation, harmful algae blooms and low dissolved oxygen (anoxia and hypoxia). The level of expression of the symptoms is determined following a set of decisions rules in which they are scored from 0 (no problem), 0.5 (moderate) to 1 (High) (Bricker et al., 1999, Appendix A).

Results based on the Primary and Secondary symptoms methods (PSM and SSM), before and after 1998, the system has improved significantly, from High to Low, in its Overall Eutrophic Condition after the implemented mitigation measures (Table 4).

\subsection{EU-Water Framework Directive and multivariate physicochemical analysis}

According to the EU-WFD (WFD CIS Guidance Document No. 5, 2003) the reference condition for a water body type is a description of the biological quality elements, which includes the physicochemical and hydromorphological quality elements that exist, or would exist, at high status. Meaning, with no, or very minor disturbance from human activities, since this "high status" provides the direction for restoration.

To assess the physicochemical status of the south arm of the Mondego estuary, according to the EU-WFD, the multivariate analysis proposed by Bald et al. (2005) was applied. The physicochemical variables used in this method correspond to annual means of nitrogen (ammonium and nitrate), phosphorus (phosphate) and percentage of oxygen saturation. This method 
Table 3

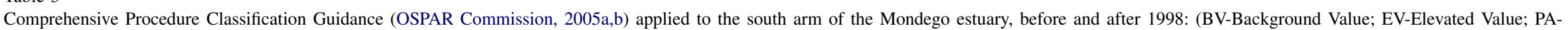
Problematic Area; PPA-Potential Problematic Area)

\begin{tabular}{|c|c|c|c|c|c|c|c|c|c|}
\hline $\begin{array}{l}\text { Assessment } \\
\text { period }\end{array}$ & Category I & Category II & Category III and IV & Classification & $\begin{array}{l}\text { Assessment } \\
\text { period }\end{array}$ & Category I & Category II & Category III and IV & Classification \\
\hline 1993-1997 & $\begin{array}{l}\text { Degree of } \\
\text { nutrient } \\
\text { enrichment }\end{array}$ & Direct effects & $\begin{array}{l}\text { Indirect effects/other } \\
\text { possible effects }\end{array}$ & & $1999-2003$ & $\begin{array}{l}\text { Degree of } \\
\text { nutrient } \\
\text { enrichment }\end{array}$ & Direct effects & $\begin{array}{l}\text { Indirect effects/other } \\
\text { possible effects }\end{array}$ & \\
\hline \multicolumn{2}{|c|}{$\begin{array}{l}\text { Riverine total } \\
\text { input of } 134 \text { tons N } \\
\text { and } 1 \text { ton P in } 1993 \\
\text { (Flindt et al., 1997) }\end{array}$} & $\begin{array}{l}\mathrm{BV}<\mathrm{Chl} a<\mathrm{EV} \\
\mathrm{BV}=5 \mu \mathrm{g} \mathrm{L}^{-1} \\
\text { Mean }=6.9 \mu \mathrm{g} \mathrm{L}^{-1}\end{array}$ & $\begin{array}{l}\text { Oxygen } \\
8.2 \pm 0.09 \mathrm{mg} \mathrm{O}_{2} \mathrm{~L}^{-1} \\
\text { (average } \pm \mathrm{SE})\end{array}$ & $\mathrm{PA}$ & \multicolumn{2}{|c|}{$\begin{array}{l}\text { Riverine total input of } 44.8 \\
\text { tons DIN and } 1.7 \text { tons DIP } \\
\text { in } 2000 \text { (Neto, 2004) }\end{array}$} & $\begin{array}{l}\mathrm{BV}<\mathrm{Chl} a<\mathrm{EV} \\
\mathrm{BV}=5 \mu \mathrm{g} \mathrm{L}^{-1} \\
\text { Mean }=6.0 \mu \mathrm{g} \mathrm{L}^{-1}\end{array}$ & $\begin{array}{l}\text { Oxygen } \\
8.1 \pm 0.08 \mathrm{mg} \mathrm{O}_{2} \mathrm{~L}^{-1} \\
(\text { average } \pm \mathrm{SE})\end{array}$ & PPA \\
\hline \multicolumn{2}{|c|}{$\begin{array}{l}\text { Winter DIN > EV } \\
\quad\left(27 \mu \mathrm{mol} \mathrm{N} \mathrm{L}{ }^{-1}\right) \\
\text { Winter DIP } \approx \mathrm{EV} \\
\left(0.85 \mu \mathrm{mol} \mathrm{P} \mathrm{L}^{-1}\right)\end{array}$} & $\begin{array}{l}\text { Data on specific } \\
\text { phytoplankton } \\
\text { species are not } \\
\text { available }\end{array}$ & $\begin{array}{l}\text { Mortality of benthonic } \\
\text { key species } \\
\text { (Ferreira et al., 2004; } \\
\text { Cardoso et al., 2005; } \\
\text { Verdelhos et al., 2005) }\end{array}$ & & \multicolumn{2}{|c|}{$\begin{array}{l}\text { Winter DIN } \approx \mathrm{BV} \\
\left(18 \mu \mathrm{mol} \mathrm{N} \mathrm{L}{ }^{-1}\right) \\
\text { Winter DIP }>E V \\
\left(0.85 \mu \mathrm{mol} \mathrm{P} \mathrm{L}^{-1}\right)\end{array}$} & $\begin{array}{l}\text { Data on specific } \\
\text { phytoplankton } \\
\text { species are not } \\
\text { available }\end{array}$ & $\begin{array}{l}\text { Recovery of benthonic } \\
\text { key species } \\
\text { (Cardoso et al., 2005; } \\
\text { Verdelhos et al., 2005) }\end{array}$ & \\
\hline \multirow{2}{*}{\multicolumn{2}{|c|}{$\begin{array}{l}\text { Winter mean } \mathrm{N} / \mathrm{P}=51.7 \\
\quad>\mathrm{EV}(46)\end{array}$}} & $\begin{array}{l}\text { Ulva } \mathrm{sp}\left(\mathrm{gAFDW} \mathrm{m}^{-2} \text { ) }\right. \\
\text { Max } 127.0 ; \text { Min } 0.0 \\
\text { Z. noltii }\left(\mathrm{gAFDW} \mathrm{m} \mathrm{m}^{-2} \text { ) }\right. \\
\text { Max 256.6; Min } 5.7 \\
\text { (Lillebø et al., 2005) }\end{array}$ & $\begin{array}{l}\text { Organic matter }(\% \mathrm{LOI}) \\
5.3 \% \pm 0.1 \\
(\text { average } \pm \mathrm{SE})\end{array}$ & & \multicolumn{2}{|c|}{$\begin{array}{l}\text { Winter mean } \mathrm{N} / \mathrm{P}=13.9 \\
<\mathrm{BV}(32)\end{array}$} & $\begin{array}{l}\text { Ulva sp (gAFDW m }{ }^{-2} \text { ) } \\
\text { Max } 13.6 ; \text { Min } 0.0 \\
\text { Z. noltii }\left(\mathrm{gAFDW} \mathrm{m} \mathrm{m}^{-2} \text { ) }\right. \\
\text { Max 158.9; Min } 18.3 \\
\text { (Lillebø et al., 2005) }\end{array}$ & $\begin{array}{l}\text { Organic matter }(\% \mathrm{LOI}) \\
4.3 \% \pm 0.2 \\
(\text { average } \pm \mathrm{SE})\end{array}$ & \\
\hline & & & $\begin{array}{l}\text { No reports } \\
\text { of nuisance or toxic } \\
\text { algal blooms }\end{array}$ & & & & & $\begin{array}{l}\text { No reports } \\
\text { of nuisance or toxic } \\
\text { algal blooms }\end{array}$ & \\
\hline+ & & + & + & & - & & + & - & \\
\hline
\end{tabular}


Table 4

Overall Eutrophic Condition (OEC) assessment (US-NEEA, Bricker et al., 1999) applied to the south arm of the Mondego estuary, before and after 1998 (SAV - Submerged Aquatic vegetation; HAB - harmful algae blooms)

\begin{tabular}{|c|c|c|c|c|}
\hline & Assessment period 1993- & & Assessment period 1999-20 & \\
\hline & $\mathrm{OEC}=\mathrm{High}$ & & $\mathrm{OEC}=\mathrm{Low}$ & \\
\hline Chlorophyll $a$ & $\begin{array}{l}\text { Moderate } \\
9.0 \mu \mathrm{g} \mathrm{L}^{-1} \\
\text { 90th percentile } \\
\text { (score of } 0.5 \text { ) }\end{array}$ & $\begin{array}{l}\text { Primary symptoms } \\
\text { High } \\
\text { (score of } 0.75 \text { ) }\end{array}$ & $\begin{array}{l}\text { Moderate } \\
9.4 \mu \mathrm{g} \mathrm{L}^{-1} \\
\text { 90th percentile } \\
\text { (score of } 0.5 \text { ) }\end{array}$ & $\begin{array}{l}\text { Primary symptoms } \\
\text { Low } \\
\text { (score of } 0.25 \text { ) }\end{array}$ \\
\hline Macroalgae & $\begin{array}{l}\text { High } \\
\text { Max } 127.0 \\
\text { Mean } 21.5 \pm 5.2 \\
(\text { gAFDW m } \\
\text { (score of } 1)\end{array}$ & & $\begin{array}{l}\text { No problem } \\
\text { Max } 13.6 \\
\text { Mean } 2.2 \pm 0.5 \\
\left(\text { gAFDW m }{ }^{-2}\right) \\
(\text { score of } 0)\end{array}$ & \\
\hline SAV & $\begin{array}{l}\text { High loss } \\
1.6 \text { ha to } 0.02 \text { ha } \\
\text { (score of } 1 \text { ) }\end{array}$ & $\begin{array}{l}\text { Secondary symptoms } \\
\text { High } \\
\text { (score of } 1)\end{array}$ & $\begin{array}{l}\text { Increase in spatial coverage } \\
0.9 \text { ha to } 1.6 \text { ha } \\
\text { (score of } 0 \text { ) }\end{array}$ & $\begin{array}{l}\text { Secondary symptoms } \\
\text { No problem } \\
(\text { score of } 0)\end{array}$ \\
\hline HAB & No problem (score of 0 ) & & No problem (score of 0 ) & \\
\hline Dissolved Oxygen & $\begin{array}{l}\text { Experience biologically } \\
\text { stressful concentrations. } \\
\text { Mortality of benthonic } \\
\text { key species } \\
\text { (score of 1) }\end{array}$ & & $\begin{array}{l}\text { No anoxia, } \\
\text { hypoxia or biologically } \\
\text { stressful concentrations } \\
\text { Recovery of benthonic } \\
\text { key species } \\
\text { (score of } 0 \text { ) }\end{array}$ & \\
\hline
\end{tabular}

requires reference conditions standards to enable the assessment of the physicochemical water quality against these standards. In absence of historical data for the Mondego estuary, and due to the relative proximity to the Basque country (Northern Spain) and similarities between systems, the same reference conditions were applied ("High" and "Bad" quality status for polyhaline water mass in Bald et al., 2005; Table 2). In Basque country estuaries have also been historically impacted and there aren't any pre-industrial historical data, thus, the respective reference conditions were calculated based on "virtual" reference locations, as an expert judgement approach (Bald et al., 2005). The range values for the physicochemical status classification (EQR values determination) were: High 0.83-1; Good 0.62-0.82; Moderate 0.41-0.61; Poor 0.20-0.40; Bad $<0.20$ (Bald et al., 2005). These classification values were achieved based upon the results of a working group within the Common Implementation Strategy of the WFD (REFCOND report, 2003 in Bald et al., 2005).
Results show that during 1993-94 the system had a "Moderate" physicochemical water quality, whilst in 2000-01 the physicochemical water quality improved to "Good" (Fig. 2).

\subsection{EU-Crouzet and others method}

The EU-Crouzet et al. (1999) method consider as physicochemical variables the annual means of nitrogen (nitrate plus nitrite) and phosphorus (phosphate). The relative concentrations of nutrients (in $\mu \mathrm{mol} \mathrm{L}{ }^{-1}$ ) were classified into four categories: Good, Fair, Poor and Bad. The respective concentrations defining each category are shown in Fig. 3.

Applying the criteria for assessment of nutrient levels in transitional, coastal and marine waters described by Crouzet and others (1999), the south arm of the Mondego estuary had always, before and after the implemented mitigation measures, a classification of "Bad" considering the concentration

\begin{tabular}{|ccccc|}
\hline Variables & $\begin{array}{c}\mathbf{O}_{\mathbf{2}} \\
(\% \mathrm{Sat})\end{array}$ & $\begin{array}{c}\mathbf{N H}_{\mathbf{4}} \\
\left(\mu \mathrm{mol} \mathrm{L} \mathrm{L}^{-1}\right)\end{array}$ & $\begin{array}{c}\mathbf{N O}_{\mathbf{3}} \\
\left(\mu \mathrm{mol} \mathrm{L} \mathrm{L}^{-1}\right)\end{array}$ & $\begin{array}{c}\mathbf{P O}_{\mathbf{4}} \\
\left(\mu \mathrm{mol} \mathrm{L}^{-1}\right)\end{array}$ \\
$\mathbf{1 9 9 3}$ & 81.8 & 27.84 & 30.72 & 2.98 \\
$\mathbf{1 9 9 4}$ & 85.5 & 28.73 & 34.84 & 3.73 \\
$\mathbf{2 0 0 0}$ & 85.9 & 8.74 & 23.57 & 3.77 \\
$\mathbf{2 0 0 1}$ & 84.1 & 10.84 & 30.79 & 3.87 \\
$\mathbf{H i g h}$ & 93.71 & 3.26 & 30.14 & 0.73 \\
Bad & 53.71 & 31.84 & 83.17 & 5.51 \\
\hline
\end{tabular}

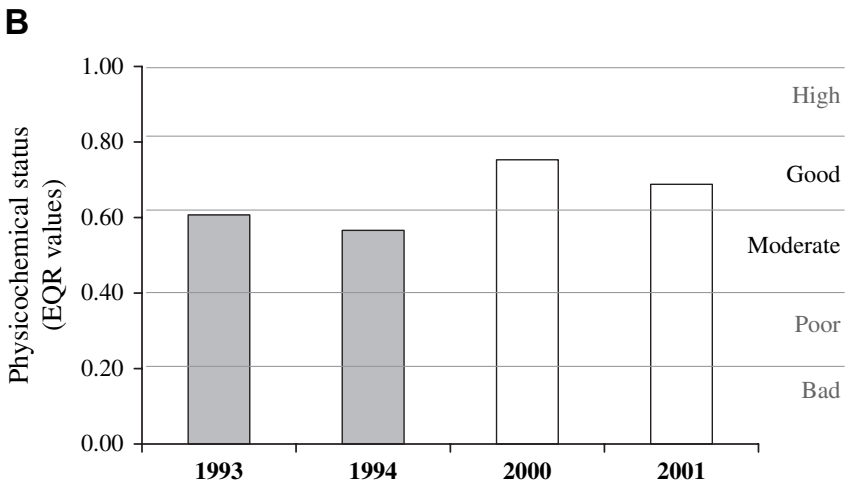

Fig. 2. (A) Variables used for the EQR determination having the Basque Country reference conditions for "High" and "Bad" quality status (Bald et al., 2005, Table 2); and (B) The EQR values and determination of the physicochemical status for the south arm of the Mondego estuary before (1993-94) and after (200001) the mitigation measures applying the method and the status classification (EQR values) proposed in Bald et al. (2005). 

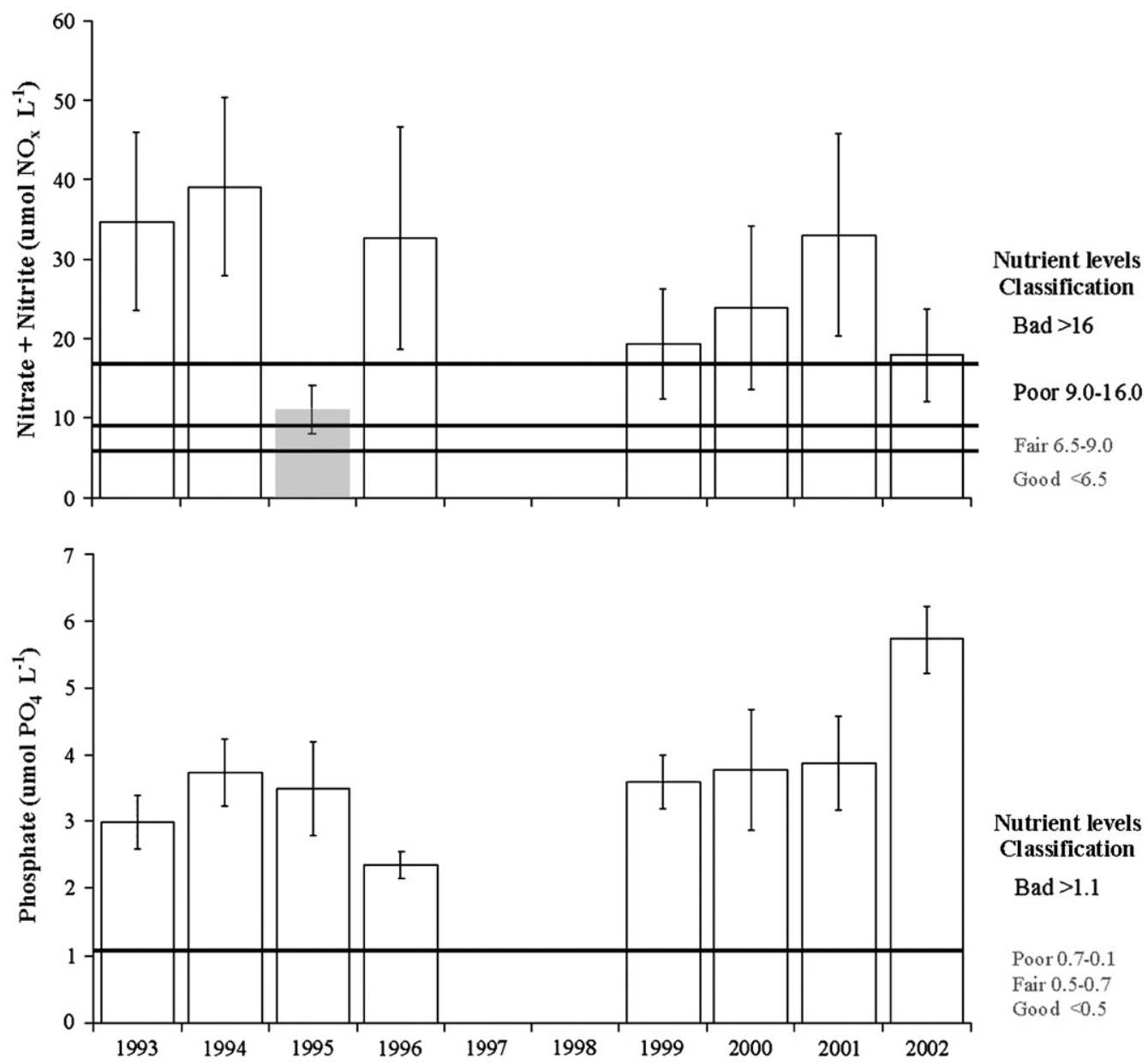

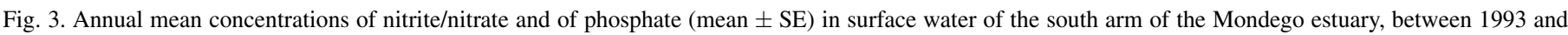
2002, and the criteria for assessment of nutrient levels in transitional, coastal and marine waters (Crouzet et al., 1999).

of the oxidised forms of nitrogen (nitrite/nitrate) and of phosphate (Fig. 3). Only in the year 1995 the classification based on the concentration of $\mathrm{NO}_{\mathrm{x}}$ was "Poor".

\subsection{Trophic classification by Wasmund and others}

The scheme for trophic classification proposed by Wasmund et al. (2001) for the Balthic Sea including coastal waters, establishes four categories (Oligotrophic, Mesotrophic, Eutrophic and Polytrophyc) based upon the annual means of phytoplankton biomass and chlorophyll $a$ from the euphotic layers, and upon the winter means of phosphate and DIN concentrations (in $\mathrm{mmol} \mathrm{m}^{-3}$ ). The respective concentrations defining each category are shown in Fig. 4.

Results show that the south arm of the Mondego estuary can be classified as "Eutrophic" attending to the mean annual concentration of chlorophyll $a$ between 1993 and 2002 (Fig. 4). Attending to the winter data (seasonal means) of DIN concentrations, the system is classified as "Polytrophic" between 1993 and 1997, and mostly "Eutrophic" after the implemented mitigation measures (Fig. 4). On the other hand, according to the winter means of phosphate the system is classified as "Eutrophic" before 1998 and as "Polytrophic" after the implemented mitigation measures (Fig. 4).

\section{Discussion}

This study reinforce that transitional waters are important ecological systems subject to a variety of socio-economics drivers, which by producing increased pressures and impacts can induce gradual changes in external conditions, such as cultural eutrophication. Ecosystem management towards restoration is a common goal for many coastal and transitional water systems (Webster and Harris, 2004) and the importance to evaluate the direction on the way to a "higher" quality status is widely recognised (e.g. Newton et al., 2003; Bald et al., 2005; Borja et al., 2006).

\subsection{Evidence of successful mitigation}

Regarding the south arm of the Mondego estuary, experimental mitigation measures undertaken in 1998 comprised the reduction of nutrient loadings from agricultural runoff directly to the south arm, a small increase of hydraulic circulation, thus reducing the water residence time, and the physical protection of seagrass meadows (Neto, 2004; Cardoso et al., 2005; Lillebø et al., 2005; Verdelhos et al., 2005). Overall, considering the different methods that fulfil the high number of monitoring requirements, the changes in assessed status 

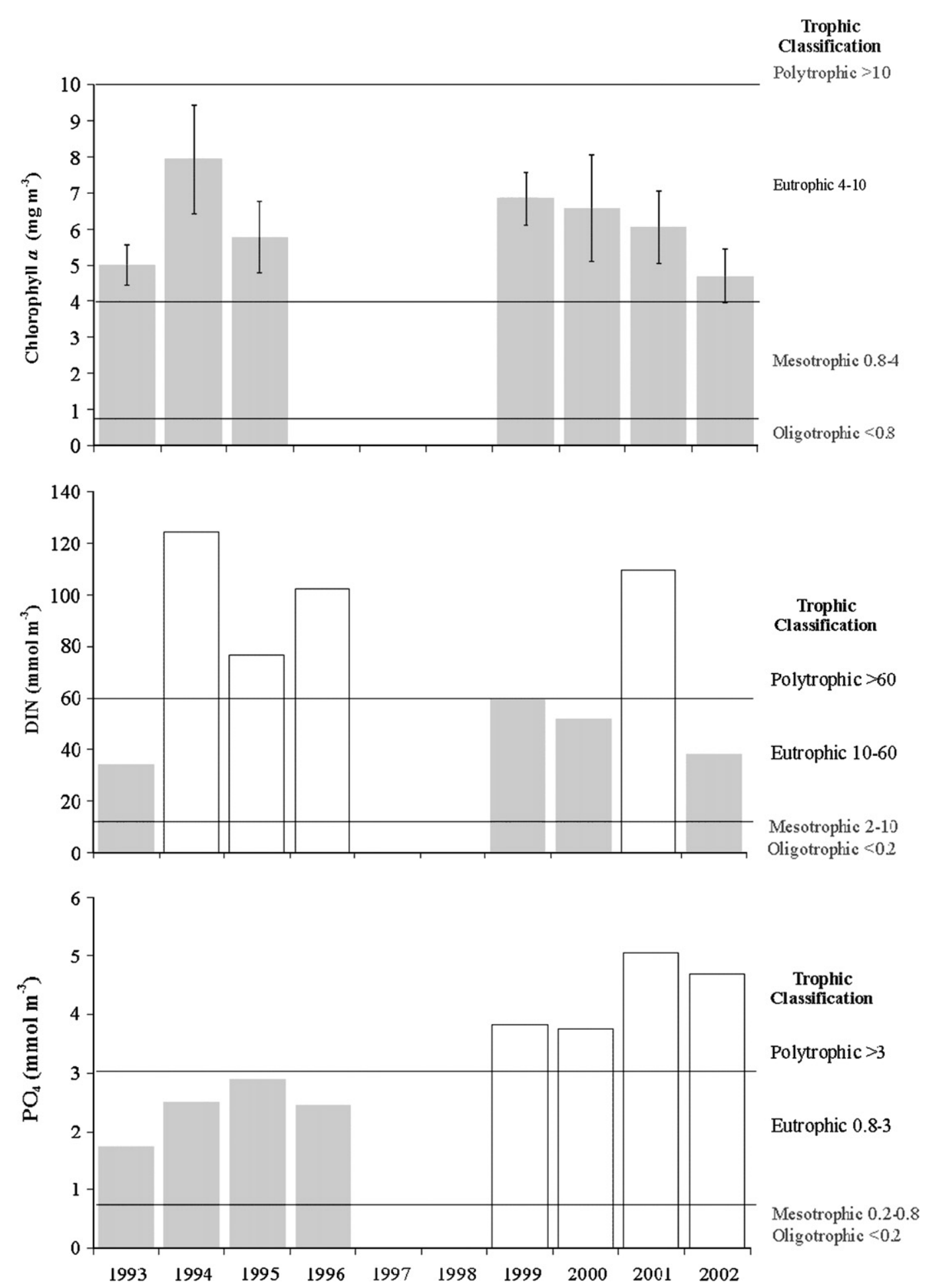

Fig. 4. Chlorophyll $a$ annual means ( $\mathrm{mg} \mathrm{m}^{-3} \pm \mathrm{SE}$ ) and seasonal means (winter) of DIN $\left(\mathrm{mmol} \mathrm{m}^{-3}\right)$ and $\mathrm{PO}_{4}\left(\mathrm{mmol} \mathrm{m}^{-3}\right)$ in surface water of the south arm of the Mondego estuary, between 1993 and 2002, and the criteria for trophic classification proposed by Wasmund et al., 2001 for the Baltic Sea including coastal waters.

of the physicochemical, hydromorphological and biological quality elements show that the system is going in the direction towards a "higher" or improved quality status (Table 5). As shown through the application of the Comprehensive Procedure Classification Guidance (Problem Area to Potential Problem area, OSPAR Commission, 2005a,b) and the change in overall expression of the Primary and Secondary symptoms of eutrophication (i.e. Overall Eutrophic Condition $[\mathrm{OEC}] \mathrm{im}$ proved from High to Low Bricker et al., 1999), the system has improved considerably. Additionally the EU-WFD multivariate analysis (Bald et al., 2005) using the reference conditions for the Basque Country, show that physicochemical water quality improved from Moderate to Good after the implementation of the mitigation measures. 
Table 5

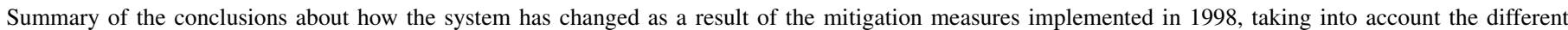
methods applied

\begin{tabular}{|c|c|c|c|c|c|}
\hline & OSPAR Convention Table 3 & US-NEEA/ASSETS Table 4 & $\begin{array}{l}\text { EU WFD Bald } \\
\text { et al. Fig. } 2\end{array}$ & EU-Crouzet et al. Fig. 3 & $\begin{array}{l}\text { Baltic sea Wasmund } \\
\text { et al. Fig. } 4\end{array}$ \\
\hline Chl $a$ (annual) & No change & No change & & & No change \\
\hline DO & Improve & Improve & & & \\
\hline Macroalgae & Improve & Improve & & & \\
\hline Benthic key spp & Improve & & & & \\
\hline DIN (winter) & Decrease & & & & Improve \\
\hline $\mathrm{NO}_{2} / \mathrm{NO}_{3}$ & & & & No change & \\
\hline DIP (winter) & No change & & & & Worsen \\
\hline $\mathrm{PO}_{4}$ & & & & No change & \\
\hline N/P (winter mean) & Decreased & & & & \\
\hline Multivariate EQR & & & Improve & & \\
\hline
\end{tabular}

\subsection{Contrary and mixed evidence suggests additional management is needed}

At the south arm of the Mondego estuary, the partial reestablishment of the upstream connection between the two arms improved the system hydraulic regime, yet the nutrient enriched freshwater diverting to the northern arm by another sluice located more upstream did not contribute to the reduction of the annual means of the oxidised forms of nitrogen and of phosphate in the system. Meaning, according to Crouzet et al., 1999 method that the system remained as "Bad" as before 1998, while according to Wasmund et al., 2001 method the system switched from "Polytrophic" to "Eutrophic" regarding DIN mean winter concentrations, mainly through the reduction of ammonium concentration. Yet it switched from "Eutrophic" to "Polytrophic" regarding phosphate concentrations.

This kind of contrary evidence in classification methods have been reported elsewhere (e.g. Newton et al., 2003), meaning that these differences have to be analyzed in detail in order to implement future management solutions. Namely, because the nutrient loads changed from 1993 to 2000: the loads of nitrogen declined, whilst the load of phosphorous increased. Thus, the improvements in the system south arm (except for the nutrient concentrations and for phosphorus loading) may not have come about only from the increased water circulation.

The main inputs contributing to the nutrient balance and status of these coastal systems are the external point and diffuse sources plus the internal biogeochemical mineralization processes, including the regeneration of nutrients from organic and inorganic matter carried by rivers. Within the major sources of nutrients to estuaries are included precipitation, freshwater flow, salt marsh production and sediment porewaters during resuspension processes. However, in estuaries near densely populated regions the nutrient supply is augmented by domestic and industrial waste waters, urban drainage and agricultural effluents (e.g. Hauxwell and Valiela, 2004). A previous study assessing eutrophication in the south arm of the Mondego estuary suggested a strong dependency of the concentration of the oxidised forms of dissolved nitrogen on the freshwater inputs from diffuse and/or point sources (Lillebø et al., 2005), which may include precipitation and freshwater flow with agricultural lands draining, as main sources of nitrate.
Phosphorus in the dissolved form $\left(\mathrm{PO}_{4}\right)$ can be strongly dependent on mineralization process (Asmus et al., 2000; Coelho et al., 2004; Lillebø et al., 2004). Yet, after 1998, the absence of a significant positive linear relation of phosphate with temperature (Lillebø et al., 2005) and the higher winter mean concentrations, implies the existence of additional sources within the south arm or through the Mondego river (north arm, Fig. 1B). Thus, as the system still receives agricultural runoff from upstream cultivated land, and as physicochemical status is seen as the supporting elements for the final evaluation of the ecological status, future measures should be implemented. In fact, an evaluation of the system in 2005 conducted to a larger scale intervention, this time formal and under the government (INAG - National Institute for Water) and local authorities' supervision, was already carried out (ended in May 2006) in which the upstream communication between the two arms of the estuary was re-established. The response of the system to the new hydrological conditions has been followed by IMAR, in the scope of a new study funded by the National authority on water resources (INAG). As nutrients concentrations are only partly due to loads, for assessing the new eutrophic conditions after the 2006 intervention, the riverine nutrient loads should also be assessed. Management at the system level should also be accomplished through the reduction of the nutrient loads, namely by improving agriculture practices in the Mondego River valley through environmental friendly technological solutions, which will constitute a longer term solution.

On a broader scale results on the Mondego system may be seen as a case study for other systems with low water residence time and eutrophication symptoms.

\section{Acknowledgements}

This work was supported by the FCT - Portuguese Foundation for Science and Technology through by the POCTI Formar e Qualificar - Medida 1.1 programme, and in part carried out within the scope of the research project EFICAS (POCI/MAR/361324/2004). The work of A.I. Lillebø was partially supported by a Post-Doc grant (SFRH/BPD/14889/2003) and partially through CESAM. 


\section{References}

Asmus, R.M., Sprung, M., Asmus, H., 2000. Nutrient fluxes in intertidal communities of a south European lagoon (Ria Formosa) - similarities and differences with a northern Wadden Sea bay (Sylt-Rømø bay). Hydrobiologia 436, 217-235.

Bald, J., Borja, A., Muxika, I., Franco, J., Valência, V., 2005. Assessing reference conditions and physico-chemical status according to the European Water Framework Directive: a case-study from the Basque Country (Northern Spain). Marine Pollution Bulletin 50, 1508-1522.

Borja, A., 2005. The European water framework directive: a challenge for nearshore, coastal and continental shelf research. Continental Shelf Research 25, 1768-1783.

Borja, A., Heinrich, H., 2005. Implementing the European Water Framework Directive: the debate continues. Marine Pollution Bulletin 50, 486-488.

Borja, A., Valencia, V., Franco, J., Muxika, I., Bald, J., Belzunce, M.J., Solaun, O., 2004. The water framework directive: water alone, or in association with sediment and biota, in determining quality standards? Marine Pollution Bulletin 49, 8-11.

Borja, A., Galparsoro, I., Solaun, O., Muxika, I., Tello, E.M., Uriarte, A., Valencia, V., 2006. The European Water Framework Directive and the DPSIR, a methodological approach to assess the risk of failing to achieve good ecological status. Estuarine, Coastal and Shelf Science 66, 84-96.

Bricker, S.B., Clement, C.G., Pirhalla, D.E., Orlando, S.P., Farrow, D.R.G., 1999. National Estuaryne Eutrophication Assessement: Effects of Nutrient Enrichement in the Nation's Estuaries. NOAA, National Ocean Service, Special Projects Office and the National Centers for Coastal Ocean Science. Silver Spring, MD, $71 \mathrm{p}$.

Bricker, S.B., Ferreira, J.G., Simas, T., 2003. An integrate methodology for assessment of estuarine trophic status. Ecological Modelling 169, 39-60.

Cardoso, P.G., Brandão, A., Pardal, M.A., Raffaelli, D., Marques, J.C., 2005. Resilience of Hydrobia ulvae populations to anthropogenic and natural disturbances. Marine Ecological Progress Series 289, 191-199.

Cloern, J.E., 2001. Our evolving conceptual model of coastal eutrophication problem. Marine Ecology Progress Series 210, 223-253.

Coelho, J.P., Flindt, M.R., Jensen, H.S., Lilleb $\varnothing$, A.I., Pardal, M.A., 2004 Phosphorus speciation and availability in intertidal sediments of a temperate estuary: relation to eutrophication and annual P-fluxes. Estuarine, Coastal and Shelf Science 61, 583-590.

Crane, M., 2003. Proposed development of sediment quality guidelines under the European Water Framework Directive: a critique. Toxicology Letters 142, 195-206.

Crouzet, P., Leonard, J., Nixon, S., Rees, Y., Parr, W., Laffon, L., Bøgestrand, J., Kristensen, P., Lallana, C., Izzo, G., Bokn, T., Back, J., Lack, T.J., 1999. Nutrients in European ecosystems. In: Thyssen, N. (Ed.), Environmental Assessment Report $\mathrm{n}^{\circ} 4$. European Environmental Agency, p. 82. http://reports.eea.eu.int/.

Directive 2000/60/EC OF THE EUROPEAN PARLIAMENT AND OF THE COUNCIL, of 23 October 2000, establishing a framework for community action in the field of water policy. Official Journal of the European Communities, pp. L327/1-L327/72.

Ferreira, S.M., Pardal, M.A., Lillebø, A.I., Cardoso, P., Marques, J.C., 2004. Cyathura carinata population dynamics in a temperate eutrophic intertidal estuary. Estuarine, Coastal and Shelf Science 61, 669-677.

Flindt, M.R., Kamp-Nielsen, L., Marques, J.C., Pardal, M.A., Bocci, M., Bendoricho, G., Nielsen, S.N., Jørgensen, S.E., 1997. Description of the three shallow estuaries: Mondego River (Portugal), Roskilde Fjord (Denmark) and the Lagoon of Venice (Italy). Ecological Modelling 102, $17-31$.

Hauxwell, J., Valiela, I., 2004. Effects of nutrient loading on shallow seagrassdominated coastal systems: patterns and processes. In: Nielsen, S. Banta, G., Pedersen, M. (Eds.), Estuarine Nutrient Cycling: The Influence of Primary Producers. Kluwer Academic Publishers, Dordrecht, The Netherlands, pp. 59-92.

Hayden, H.S., Blomster, J., Maggs, C.A., Silva, P.C., Stanhope, M.J., Waalland, J.R., 2003. Linnaeus was right all along: Ulva and Enteromorpha are not distinct genera. European Journal of Phycology 38, 277-294. de Jonge, V.N., Elliot, M., Brauer, V.S., 2006. Marine monitoring: Its shortcomings and mismatch with the EU Water Framework Directive's objectives. Marine Pollution Bulletin 53, 5-19.

Lillebø, A.I., Flindt, M.R., Pardal, M.A., Marques, J.C., 1999. The effect of macrofauna, meiofauna and microfauna on the degradation of Spartina maritima detritus from a salt marsh area. In: Marques, Gamito, Ré (Eds.), Processes and Flows in Marine Benthic Ecosystems. Acta Oecologica 20 , pp. 249-258.

Lillebø, A.I., Neto, J.M., Flindt, M.R., Marques, J.C., Pardal, M.A., 2004. Phosphorous dynamics in a temperate intertidal estuary. Estuarine, Coastal and Shelf Science 61, 101-109.

Lillebø, A.I., Neto, J.M., Martins, I., Verdelhos, T., Leston, S., Cardoso, P.G., Ferreira, S.M., Marques, J.C., Pardal, M.A., 2005. Management of a shallow temperate estuary to control eutrophication: the effect of hydrodynamics on the system nutrient loading. Estuarine, Coastal and Shelf Science 65, 697-707.

Limnologisk Metodik, 1992. Ferskvandsbiologisk Laboratorium. In: Universitet, Københavns (Ed.). Akademisk Forlag. København, 172 pp.

Marín-Guirao, L., Cesar, A., Marín, A., Loret, J., Vita, R., 2005. Establishing the ecological quality status of soft-bottom mining-impacted coastal water bodies in the scope of the Water Framework Directive. Marine Pollution Bulletin 50, 374-387.

Meeuwing, J.J., 1999. Predicting coastal eutrophication from land-use: an empirical approach to small non-stratified estuaries. Marine Ecology Progress Series 176, 231-241.

Neto, J.M., 2004. Nutrient enrichment in a temperate macro-tidal system. Scenario analysis and contribution to coastal management. $\mathrm{PhD}$ Thesis in Biology. University of Coimbra, $139 \mathrm{p}$.

Newton, A., Icely, J.D., Falcao, M., Nobre, A., Nunes, J.P., Ferreira, J.G., Vale, C., 2003. Evaluation of eutrophication in the Ria Formosa coastal lagoon, Portugal. Continental Shelf Research 23, 1945-1961.

OSPAR Commission, 2005a. Ecological Quality Objectives for the Greater North Sea with Regard to Nutrients and Eutrophication Effects, 229, 33 p. OSPAR (Protection of the Marine Environment of the North-East Atlantic) publications, (ISBN 1-904426-71-9). http://www.ospar.org/eng/ $\mathrm{html} /$ welcome.html.

OSPAR Commission, 2005b. Synergies in Assessment and Monitoring between OSPAR and the European Union, 230, 67 p. OSPAR (Protection of the Marine Environment of the North-East Atlantic) publications, (ISBN 1-904426-72-7), http://www.ospar.org/eng/html/welcome.html.

Parsons, T.R., Maita, Y., Lalli, C.M., 1985. Pigments. A Manual of Chemical and Biological Methods for Seawater Analysis. Pergamon Press, pp. 101104

Salas, F., Neto, J.M., Borja, A., Marques, J.C., 2004. Evaluation of the applicability of a marine biotic index to characterize the status of estuarine ecosystems: the case of Mondego estuary (Portugal). Ecological Indicators 4, 215-225.

Strickland, J.D.M., Parsons, T.R., 1972. A Practical Handbook of Seawater Analysis (Bulletin 167, second edition). Fisheries Research Board of Canada, Ottawa, pp. 71-80.

Teixeira, H.L., Salas, F., Pardal, M.A., Marques, J.C. Applicability of ecological evaluation tools in estuarine ecosystems: the case of Mondego Estuary (Portugal), Hydrobiologia (in press).

Verdelhos, T., Neto, J.M., Marques, J.C., Pardal, M.A., 2005. The effect of eutrophication abatement on the bivalve Scrobicularia plana. Estuarine, Coastal and Shelf Science 63, 261-268.

Wasmund, N., Andrushaitis, A., Lysiak-Pastuzak, E., Müller-Karulis, B., Nausch, G., Neumann, T., Ojaveer, H., Olenina, I., Postel, L., Witek, Z., 2001. Trophic status of the south-eastern Baltic sea: a comparison of coastal and open areas. Estuarine, Coastal and Shelf Science 53, 849-864.

Webster, I.T., Harris, G.P., 2004. Anthropogenic impacts on the ecosystems of coastal lagoons: modelling fundamental biogeochemistry process and management implications. Marine and Freshwater Research 55, 67-78.

WFD CIS Guidance Document No. 5, 2003. Common Implementation Strategy for the Water Framework Directive (2000/60/EC). Transitional and Coastal Waters-Typology, References Conditions and Classification Systems, 116 pp. http://europa.eu.int/comn/environment/pubs/home.htm. 